\title{
The ambivalence of ritual in violence: Orthodox Christian perspectives
}

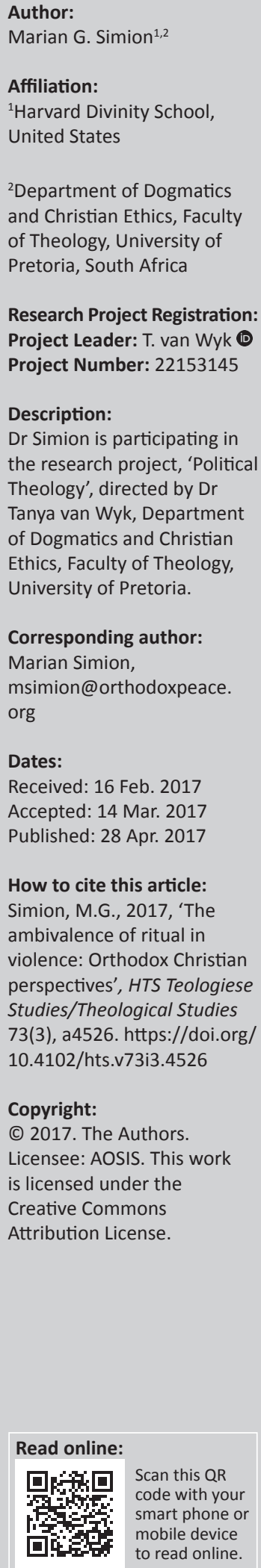

This article demonstrates that ritual plays an ambivalent role in the interaction between religion and violence. Ritual triggers and gives meaning to violence, or it enforces peace and coexistence. The first part of the article defines the ambivalence of ritual in the context of violence. The second part surveys standard rituals of peace and violence from Hinduism, Buddhism, Judaism, Christianity and Islam. The third part focuses on the ambivalent nature of Orthodox Christian rituals.

\section{Introduction}

Religion is a phenomenon that inspires trust, love, joy and awe as much as it inspires fear, terror, pain and suffering. It does so through narratives that are moving or terrifying, through rules that are soft or draconian, and through rituals that either stimulate pleasure or inflict pain or even death. The power of ritual dwells upon the ability to emotionally manipulate the individual through various motivational symbols that operate with social abstractions and give life its meaning. Neither a philosophical impression nor any law possesses such power to weld together the individuals into a homogeneous group as ritual does.

\section{The ambivalence of ritual What is ritual?}

To define what ritual is in its essence is a daunting matter. However, it becomes easier to describe or explain what ritual does.

In sociologic terms, ritual represents one of the three pillars of belief, which together with doctrine and ethics make up what is known as an organised religion. These three pillars make up the structure of religion in its most basic character, and they can be found in any form of religious activity from any place, and any time in history. Because religion attempts to answer the most basic questions of human self-awareness - who am I, where do I come from and what my final destination is - the answers it provides become part of the pilgrimage from the origins to the final destination. In other words, religion tells a good story (doctrine) and devises a specific conduct to be observed on the path between origins and destination (ethics) through a distinctive symbolic behaviour that creates meaning (ritual). This logic of defining religion along these three pillars of belief resonates also with the way Emile Durkheim (1969) defined religion, as:

a unified system of beliefs and practices relative to sacred things, that is to say, things set apart and forbidden beliefs and practices that unite into one single moral community called a Church, all those who adhere to them. (p. 62)

The functional role of ritual is to inspire the seeker to bring order in a context dominated by chaos, to create collective certainty in times of ambiguity, to create new meaning, to redefine or to dismantle an extinct intimation in a spiritually controlled ambiance. This is because, as logotherapy informs, people need meaning to survive (Frankl 1984:119-179) or, as Karen Armstrong (2014) writes, '[w] are meaning-seeking creatures and, unlike other animals, fall very easily into despair if we fail to make sense of our lives' (p. 6).

Rituals also separate the structure of life between matters that are numinous and foul. While numinous matters are charged with moral significance and symbolic truisms, foul matters are symbolically rejected and accursed. This is because, within the ambiance of ritual, sacredness is created, recreated and enforced.

Rituals are also anchored in the objectification of symbols and the feat of repetitiveness (Jönsson \& Hall 2005:6). When skilfully manipulated by the ritual performer, a symbol (or system of symbols) 
(Bell 1992:26-27) allows a person's imagination to run its rampant course, thus making the person vulnerable to taking action either individually or collectively. Communal rituals charge the person emotionally through formality and repetitiveness, so that the person will have a different moral perception of reality. In fact, the strongest social attitudes are formed and enforced through ritualism and symbol manipulation, and by implication, whoever controls the symbols of ritual has direct access to the toolbox of power control (Kertzer 1988:9).

\section{Ritual and violence}

Religion performs violence through ritual in symbolic and realistic ways, and as such, ritual has a central place in religious violence. Symbolic violence is often the precursor of real violence because it anticipates, stirs and prepares the individual for an upcoming confrontation. By demonising adversaries, symbolic violence charges the foe with the most repulsive and dangerous qualities which need not to be avoided only but eliminated altogether.

Whether performed against an external foe or against an internal suspect, religious violence contains a strong variety of rituals that may impose torture and terror against the intruder, as much as they can impose punishment for defying civic rules or the potentate.

\section{Initiation rituals}

Based on archaeological data, the earliest forms of religious violence were mostly associated with totemic rituals, ancestors worship, animism and rites of passage. Sacred pain was administered to make one worthy of being part of the group, or to be accepted by the gods. To prove worthy one had to accept self-mutilation, self-inflicted pain, deprivation, starvation, penitence, genital mutilation, self-mortification and even suicide (Alcorta \& Sosis 2013:570-577). Today, as Condace S. Alcorta and Richard Sosis note:

prolonged kneeling, standing, and prostration; fasting; sleep deprivation; dancing to exhaustion; self-flagellation; and bodily mutilation are common practices across religious traditions. (p. 578)

The rationale of the initiation rituals can be understood and explained primarily as the group's attempt to ensure the cooperation of each member. By administering sacred pain, the group tests the future member's loyalty and readiness to die. To investigate this, the uninitiated has to be tested via rituals which in some cases involve beatings; isolation; deprivation of food, water and sleep; bodily mutilations and torture. The psychological benefit of such experience is that it increases the self-worth of the uninitiated, while the group becomes (re)sanctified and reinvigorated in its cohesiveness by the experience of ritual itself. As Condace S. Alcorta and Richard Sosis write:

$[v]$ iolent and painful initiation rites sanctify group values, increase levels of aggression, and neuro-physiologically bond 'brothers in arms'. As a result, such rites are likely to produce the most cohesive groups and the most effective warriors. Military boot camps and paramilitary terrorist training camps effectively employ violence and pain to the same end. (p. 582)

\section{Sacrifice and scapegoat}

The primitive societies understood that intragroup violent competition could threaten the survival of the group. As the fury of the competitors turned deadly and could not be stopped, it was crucial to release it into something else; perhaps an external entity which lacked the capacity to retaliate.

The external entity, or the scapegoat, not only absorbed the fury of the competitors but also ended the deadly competition. With the destruction of the scapegoat, the peace of the group was re-established, and the sacred - that is the delimitation between matters that are numinous and foul - was recreated through sacrifice (sacer, 'holy'; facere, 'to make').

Capitalising upon the initial success of the sacrifice, the leader has to remind his community that any deadly competition ought to be avoided. He does so by re-enacting the sacrifice with regularity; only this time as a symbolic expression and with non-human victims. This is a pedagogical event in which the entire group has to participate. As René Girard noted, the use of this limited violence in the context of sacrifice becomes 'nothing more than the regular exercise of "good" violence', (Girard 1979:37) which demonstrates that religion is a source of stability. Such perception of sacred violence can be observed throughout the historical development of religion. The Hindu gods, the Greek gods and the Aztec gods demanded the sacrifice of the beloved one, as much as Jahveh did of Abraham's son (Carrasco 2013:210-222).

\section{Preemptive justification of violence}

One might be tempted to regard ritual violence as a contested area of the just war thinking because of the natural ambiguity projected by the symbol itself within the logic of causality. In spite of this temptation, it is a fact that political rituals are infused with acts of symbolic violence. Such symbols not only coagulate human emotions in face of potential violence but also become platforms that justify preemptive strikes. In this sense, the desecration of a sacred place or object, or the spiritual offense brought against a holy person, represents taboos that cannot be broken (Little 2010:237). Once broken, a taboo constitutes a casus belli such as in the case of Charlie Hebdo's cartoons (deriding Prophet Muhammad), which unleashed Muslim retaliation through terrorist acts and violent protests around the world (Bilefsky \& De la Baume 2015). Similarly, the desecration of holy places such as the demolition of Ferhadija and Arnaudija mosque complexes in the city of Banja Luka, by the Serbian Orthodox political elite from Belgrade in 1993 (Walasek 2015:26-30), led to the desecration of the Serbian Orthodox Churches in Kosovo by the Albanian Muslims (Rakitic 2014:191-242). Yet, the preemptive justification of violence is not only the domain of organised religion, as the secular state uses it in a similar manner. According to the 
Just War theory, one of the jus ad bellum prerequisites for a just cause includes the desecration of the national symbols. ${ }^{1}$ Internally, countries such as India criminalise and persecute any citizen who insults national symbols such as the emblem, name, flag or the national anthem (Government of India 2011:1). While certain secular states have issued specific laws that prosecute flag desecration exclusively (Welch 2000), in North Korea, even pointing a finger at a statue or a painting of a political leader, or pointing a finger at a slogan carved in stone, is considered a severe crime against the communist state. ${ }^{2}$ Therefore, the power of ritual expressed as symbolic violence is far from being reckoned as irrelevant to the just war thinking. Even if evading their own visibility, rituals of preemptive violence act as aggregates that determine the course of collective action during social hostilities.

Conclusively, religion endorses and sustains both peace and violence by providing spiritual narratives that give meaning to life and death, and by altering or changing the moral standards of the community. The relationship between the spiritual narratives and the moral standards is solidified in the public consciousness through the power of ritual.

\section{Ritual and violence in world religions \\ Is religion inherently violent?}

Qualitative empirical studies have demonstrated that in its essence, religion is a phenomenon of trust and stability (Girard 1979), while in its institutionalised form it becomes a source of peace or violence, as mandated by interests (Simion 2012).

In its history, the comfort that religion took with real and symbolic violence had been expressed through rituals of 'bloody' and 'bloodless' sacrifices which displaced the deadly fury of rivals into a scapegoat that was unable to retaliate. As such, scapegoating rituals became instruments for social stability, and tools for acquiring political power.

Today, the relationship between ritual and violence in organised religions continues to follow the pattern of ambivalence. Contemporary religions, such as Hinduism, Buddhism, Judaism, Islam and others, display complex ecosystems in which rituals are used either to generate peace and understanding, or to radicalise their followers, by demonising adversaries and justifying violence against them. Even if disguised as innocent melodramas of cultural expression, the furtive power of rituals goes hand in hand with doctrinal teachings and sacred texts, as they craft new patterns of behaviour.

1.Cf. BBC Ethics Guide http://www.bbc.co.uk/ethics/war/just/cause_1.s. shtml, viewed on 05 February 2017

2.Insofar as my own testimony counts as evidence, in 2008, when I visited North Korea, I was instructed not to point fingers at anything, particularly at slogans, as this was regarded by the authorities as deeply insulting, and as a potential crime against the leader.

\section{Hinduism}

In Hinduism, ritual violence was developed during the Brahmanic period (BC 1000 through AD 400) on the venues of dharma and yoga. Dharma interpreted the order of the Vedic animal sacrifice, and it imposed social conformity in a discriminatory and violent fashion. As Hermann Oldenburg explained, the Vedas imposed the killing of the animal in order 'to free oneself from the sin of a bloody deed, and from impending revenge' (Oldenburg 1988:292). Anchored in the tradition of the ascetics (tapasvin), yoga interiorised the Vedic sacrifice within the concept of mental liberation (mokşa) through meditation and nonviolence. If the path of dharma offered detailed rituals of violence, the path of yoga developed specific mental techniques to destroy violence from its roots that are found in the human heart (Nayak 2000:66-67).

\section{Buddhism}

As the recent events in Sri Lanka demonstrate (Gregg 2014:7475), reality defies the popular perception of Buddhism as a religion of peace. In a positive sense, the goal of a Buddhist monk is to attain enlightenment and become a bodhisattva; that is a saint who deeply embodies the quality of nonviolence (Nayak 2000:176). This is done through meditation and rituals that generate peace and nonviolence. In attaining enlightenment, for the regular believer it is imperative that a ceremonial reading be practised twice a month, so that 'anger must be overcome by the absence of anger; evil must be overcome by good; greed must be overcome by liberality; lies must be overcome by truth' (Ferguson 1978:46). Negatively, there are instances in which Buddhism considers ritual killing to be a path towards enlightenment and towards attaining instantly the status of bodhisattva. For instance, in AD 515, the Chinese ruler Fa-ch'ing led an army of 50000 rebels and announced that any of his troops who killed an enemy will become a bodhisattva on the spot (Ferguson 1978:52).

Mahayana Buddhism identifies five circumstances in which the act of killing is justified and commended as a ritual act. (1) Mahaparinirvana Sutra claims that in a previous life, Buddha killed a Brahmin to protect the accuracy of the doctrine. (2) Several spiritual narratives praise a Buddhist monk who killed a bandit plotting to assassinate and rob 500 merchants thus saving 500 lives at the expense of one - and everyone was spiritually saved. In some variants of this narrative, the killer-monk is the Buddha himself. (3) If the Buddha taught that everything is an illusion, then killing does not exist because there is no soul or self; therefore nothing to kill. (4) The prominent Buddhist philosopher Asanga recommended that it is better to kill than to be killed. (5) As everything is predestined, the act of killing must be part of one's destiny, and as such it becomes permissible (Ferguson 1978:55-56).

\section{Judaism}

Biblical Judaism often combined the act of worship with war, whereby a prayer had a direct impact over the success of the military. One classical sample of such ritual behaviour which was adopted by Christianity and Islam - is the episode 
from Exodus in which the success of Israel depended on Moses being able to raise his hands in prayer:

As long as Moses held up his hands, the Israelites were winning, but whenever he lowered his hands, the Amalekites were winning. When Moses' hands grew tired, they took a stone and put it under him and he sat on it. Aaron and Hur held his hands up - one on one side, one on the other - so that his hands remained steady till sunset. So, Joshua overcame the Amalekite army with the sword. (Ex 17:11-13)

At the same time, violence-oriented rituals invoke ritual killing of enemies (including their livestock), as an act of worship; often performed on the basis of mythical battles against Israel's mortal enemies (Eisen 2011:25).

However, Biblical Judaism included also the nazirite rituals (Num 6:1-21), which were personal peace-offering vows that an individual took to become 'holy unto the Lord'. Nazirism was preceded by additional rituals of purification which involved abstinence from alcohol, from cutting hair, from touching corpses and the avoidance of graveyards. Nazirite rituals included the practice of sacrifices such as the olah [lamb as a burnt offering], the hatat [sheep as sin-offering] and the shelamim [ram as peace offering].

Contemporary Jewish rituals continue to express religious ambivalence. The peace-oriented rituals involve morning prayers (shacharit), afternoon prayers (mincha) and evening prayers (ma'ariv, or arvit), as well as Friday night and Saturday morning services. The evening prayers include a particular peace invocation such as: 'Lay us down to sleep, Adonai, our God, in peace, raise us erect, our King, to life, and spread over us the shelter of your peace' (Martin 2005:35). Regarding contemporary violence, as Robert Eisen (2011) writes, 'Judaism has inspired violence not just in religious Zionism, but in secular Zionism as well' (p. 145). An example involving ritual killing is the assassination of Israel's Prime Minister, Yitzhak Rabin by Yigal Amir. Prior to the assassination, Amir allegedly received the blessing of a Rabbi and declared that he acted according to din rodef [law of the pursuer] to commit extrajudicial killing (Pedahzur \& Perliger 2009:106-107).

\section{Islam}

The peaceful and the violent aspects of the Muslim rituals are linked with the centrality of Mecca, and with the question of leadership. Muslim worship takes several forms such as salat [ritual prayer], dhikr [contemplative prayer] and dua [prayer of praise or exhortation]. The ritual involves a prostration towards Kaba from Mecca, which is performed daily (morning, noon, mid-afternoon, sunset and evening), and it is practised at home or in the mosque. Public prayer is preceded by adhan [call to prayer], which is recited from a minaret, and it includes statements such as the takbir [God is most great], the shahada [there is no god but Allah, and Muhammad is the messenger of Allah], and the imperative 'hurry to salat' (Ruthven \& Nanji 2004:14).
One of the five pillars of Islām is the Hajj [or the pilgrimage to Mecca], which each Muslim has to perform at least once in a life time. The Hajj culminates with a ritual called, 'stoning the devil' which denounces Satan's temptation of Abraham, and by extension, of the entire Muslim community. The importance of this ritual is significant as it promotes a dramatic release of frustration into a virtual scapegoat and not into a human being.

In Islam, rituals of violence are conducted prior and during military confrontations; mainly as acts of encouragement, and as forms of spiritual discipline designed to ensure that the battle is conducted for the benefit of Islam. Ritual violence is directed against external enemies, as well as internally, as a devotional symbol. When directed against external enemies, Islam practises two chants for mobilisation, the shahada and Allahu Akbar [Allah is the Greatest]. The shahada - La ilaha il Allah, Muhammad-ur-Rasool-Allah ['there is no God but Allah and Muhammad is his prophet' - is a chant that prepares the crowd for a violent confrontation]. However, when the moment of attack is imminent, the Allahu Akbar chant is used. According to Islamic tradition, Allahu Akbar was prescribed by Prophet Muhammad to each mujahedeen [holy fighter] to ensure spiritual legitimacy when fighting 'on the path of Allah'. As an internal devotional symbol, the Ashūra ritual of the Shiite tradition is observed with a dramatic display of self-inflicted wounds. The pain imposed through selfflagellation has strong emotional consequences, explaining perhaps the ease of willingness to conduct jihad and martyrdom (Bowker 1997:99).

\section{Ritual ambivalence in Orthodox Christianity}

In Orthodox Christianity, the relationship between ritual and violence subscribes to the general configuration of religious ambivalence.

The metaphorical representation of violence through symbols, rites, rituals and sacred art plays a significant role in the way Christianity understands itself. Symbols of violence such as cross and blood were given opposite meanings through the power of ritual. While for Roman criminal justice the cross served as an effective tool to maximise pain and suffering, Paul took it to represent sacrifice, redemption and human salvation; and thus it became an object of veneration. On the same token, the meaning of the blood that Jesus of Nazareth shed on the cross was redefined to represent the glory of salvation through the bloodshed of martyrdom.

\section{Defining Orthodox ritual}

Defined from within, the Orthodox ritual represents the totality of acts, forms and holy establishments through which the Church honors God, and administers the sanctifying grace to the believers' (Braniște 1978:5). The ritual recreates a complex and symbolic world that parallels, mimics and even mocks the drama of the human condition. It replicates the deficiencies of human society by reaffirming idiosyncrasies 
such as social inclusion and exclusion, reward and punishment, and superiority and inferiority.

The ambivalence of ritual is perhaps best represented by the Eucharist; the most significant ritual of Orthodox Christianity. While, in an allegoric sense, the Eucharist is a 'cosmic liturgy' which includes and celebrates the entire creation - should one take Maximus the Confessor in a literal sense (Urs von Balthasar 2003:324-325) - in reality, the physical participation in the epiclesis (the summit moment when the priest invokes the blessing power of the Holy Spirit, and the bread and wine become the Eucharistic body and blood of Jesus Christ), remains the exclusive privilege of those who have been baptised, illuminated, anointed with the holy myrrh, hallowed and washed clean (Greek Orthodox Archdiocese of America 2017); therefore Orthodox. This exclusiveness is further dramatised once the prospective candidates to Orthodoxy (the catechumens) have been asked to leave the church, the doors are closed behind them, then the liturgy continues to the epiclesis.

In Orthodoxy, any liturgical act ought to echo the spiritual teachings of the Church, while also reminding the believers what moral conduct is expected of them. The language has to be carefully selected in order to accurately reflect and even impose the dogmatic teachings. A theologumena, or a theological opinion which does not contradict any dogma, has to be crafted in such a way as to modify the innermost spiritual universe of the believer and align it with the official standards. In other words, a theologumena represents the negotiation zone between truth and heresy, which only the emotional stir of the ritual can fully control.

\section{Structure of ritual}

In general terms, the Orthodox Christian ritual has to be centred on Jesus Christ, and it has to be structured around the history of salvation (Braniște 1993:128-137). It also has to be synchronised and performed in full resonance with the social structure it replicates, within a specific liturgical time, in a specific locus and in the appropriate forms of expression (Braniște 1993:5-7).

The subject of worship is man, and the object is God. As such, man's worship is supreme and relative. It is supreme because this has to be offered to God alone in the form of adoration $(\lambda \alpha \tau \rho \varepsilon i \alpha)$, and relative because the Church prays to saints, to celestial beings, to crosses, icons, and to relics in the form of

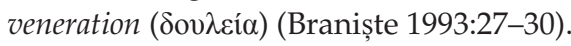

The social structure replicated by the ritual is exclusively hierarchical. As a representation of an ideal world, the Church is considered infallible in its Christ-centred hierarchical structure, while its members, including the clergy, are considered fallible indeed (Biserica Ortodoxă Română 2000:136). ${ }^{3}$

3.Biserica Ortodoxă Română, 2000, învățătură de credință creștină ortodoxă, tipărită cu aprobarea Sfântului sinod al Bisericii Ortodoxe Române (București: Editura Institutului Biblic și de Misiune al Bisericii Ortodoxe Române).
The public control of ritual is the exclusive privilege of the clergy. The Orthodox clergy follow a very clear hierarchy which has specific ranks and specific duties. It includes superior clergy - progressing from deacon to priest with the bishop at the summit - and inferior clergy, which progresses from the reader to the cantor, culminating with the rank of the sub-deacon (Biserica Ortodoxă Română 2000:279).

As for laity, their public role in the ritual is limited to various chores, such as ushers, grave diggers, bell ringers and others, as needed by the community. Except for extreme cases, Orthodox laity is never entrusted with the leading of the ritual, even though the Early Church included exorcists, acolytes and deaconesses (Braniște 1993:41-43).

The gender ambivalence of ritual is revealed by the dichotomy between contents and performance. While ritual includes female saint veneration and reputes Virgin Mary as 'more honorable than the Cherubim, and more glorious beyond compare than the Seraphim' - that is above the world of the celestial beings - down on earth women are excluded from joining the superior clergy (Behr-Sigel \& Ware 2000). Their privilege of ordination is simply denied.

In the Orthodox understanding time is Christ-centred, and it is organised in line with the narrative of salvation. Within each ritual, time is not only confined to reflect a specific history - bracketed by the beginning and the end - as it also operates with the concept of eternity. In a dogmatic sense, the coexistence between time and eternity is implied by Trinitarian antinomies such as the Father, the Son and the Holy Spirit, which are eternal, and yet the Father permanently gives birth to the Son and permanently proceeds the Holy Spirit (Todoran \& Zăgrean 1991:125). Furthermore, the coexistence between human history and eternity is reflected in the hypostatic union between the human nature and the divine nature that coexist in Jesus Christ, united without confusion, undividedly and inseparably (Todoran \& Zăgrean 1991:222-228).

In the Eucharist the anamnesis [or remembrance] which precedes the epiclesis of the Eucharist, time is no longer limited to a beginning and an end as it becomes an expression of eternity and everlasting life. The living and the dead become full participants in the Eucharist, and they are symbolically represented by the merides ( $\mu \varepsilon p i$ íos small crumb of bread) which are placed on the paten around a squared piece of bread, which is divided by a cross inscribed with the letters I $\Sigma$ X $\Sigma$ NI KA [Jesus Christ Conquers], and which is considered to be the Eucharistic body of Christ. Therefore, during the Eucharistic moment human history and eternity overlap.

As a longitudinal sequence of events, time is organised in line with the saga of salvation, and the liturgical calendar is organised in line with Christ's role of prophet, priest and king. Christ's role of prophet is underscored by the range of feast days that make up the period of the Octoechos, the role of priest by the Triod and the role of king by the 
Pentecostarion (Braniște 1993:135). In terms of beginning and end, the early Christians adopted the Jewish civil calendar as their ecclesiastic year (which started on September 01 and ended on August 31) (Braniște 1993:133), but this was incrementally removed from being associated with Judaism. Instead, it became associated with the feminine self-understanding of the Church (bride of Christ), by being flanked by Virgin Mary's nativity at the beginning (September 8) and her dormition at the end (August 15).

Liturgical time also involves time set aside for personal devotion of the believer. Aiming toward the forgiveness of sins and the eternal life, the Orthodox devotion includes periods of time dedicated for spiritual exercise to be practised in the form of thought control and physical abstinence.

\section{Ritual and warfare}

As an exercise of devotion, the Orthodox ritual focuses primarily on the individual and less on the group. Guilt, which can only be expiated through acts of sacrifice, gave rise to extreme forms of manifestation culminating with martyrdom. As physical needs often pose grave dilemmas in one's struggle for spiritual ascent, the act of devotion itself came to be interpreted as a form of spiritual warfare, particularly by the desert fathers and the philokalic tradition in general.

Focused on the concept of spiritual warfare, whereby a war ought to be declared against human passions and negative thoughts which undermine one's salvation (Scupoli 1952), the manifestation of such spiritual warfare took the form of severe asceticism and self-mortification. For instance, an Egyptian spiritual narrative tells how Saint Dorotheus (Theban Ascetic) practised his devotion:

\begin{abstract}
All day long in the burning heat he would collect stones in the desert by the sea and build with them continually and make cells, and then he would retire in favor of those who could not build for themselves. Each year he completed one cell. And once when I said to him: 'What do you mean, father, at your great age by trying to kill your poor body in these heats?' And he answered thus: 'It kills me, I kill it.' I never knew him stretch his legs and go to sleep on a rush mat or on a bed. But he would sit up all night long and weave ropes of palm-leaves to provide himself with food. (MacDermot 1971:304)
\end{abstract}

The harsh treatment of one's own body was performed because it was the body that caused the spiritual failure of the monk. For a monk, this failure was similar to that of the lapsi from the Early Church, who, out of fear of pain, have abandoned the faith during persecutions and sacrificed to the Roman gods. The extreme forms of self-mortification and self-punishment were often debated by the spiritual elders, particularly as Paul considered the human body to be the temple of the Holy Spirit (1 Cor 6:19).

\section{Justification of war}

On account of its spiritual infallibility, the Orthodox Church has never adopted a Just War theory (Simion 2015:188-206). While local Orthodox Churches defended the morality of wars conducted in self-defence, offered rituals of blessing weapons and military symbols, and even adopted the language of the Just War theory, the Orthodox Church has never justified war at a pan-Orthodox level. The document titled The Mission of the Orthodox Church in Today's World adopted during the Holy and Great Council of the Orthodox Church in 2016, the participants stated the following:

The Church of Christ, which understands war as essentially the result of evil and sin in the world, supports all initiatives and efforts to prevent or avert it through dialogue and every other viable means. When war becomes inevitable, the Church continues to pray and care in a pastoral manner for her children who are involved in military conflict for the sake of defending their life and freedom, while making every effort to bring about the swift restoration of peace and freedom.

During war, the Orthodox Church prayed for peace, and also warned its members not to kill, for killing in war was still murder. For instance, Canon 13 of Basil the Great stated that any soldier who killed on the battlefield was to be deprived from receiving communion for 3 years (Mantzaridis 2012:119). With martyrdom as the ideal way of embracing the paradise, the attitude was simply reduced to the logic that it is better to be killed than to kill, and it challenged the moral authority of erratic sovereigns. ${ }^{4}$ Dying an innocent death becomes a gateway towards immortality, because the killer deprives the victim from the opportunity to repent. In fact, immortality and paradisiacal life can only be attained via two exclusive paths' - martyrdom or pious life - criteria used to recognise sainthood.

In the contemporary context, the collective Orthodox thinking favours an obvious sense of ambivalence. For instance, while the Russian Orthodox Church blesses weapons of mass destruction as a show of aggression of the Russian state (Simion 2011:162), the Coptic Orthodox Church of Egypt not only failed to retaliate against the ritual beheading ${ }^{5}$ of the 21 Egyptian Orthodox men by ISIL in Tunisia in 2015, but it canonised the victims as martyrs (Arocho 2015) and continued to send messages of forgiveness to their killers.

\section{Ritual and the military}

During the late 6th century, the Byzantine military manuals started to include specific guidelines for religious rituals to be performed in the military camps before and during battle. The rituals included blessings of soldiers, blessings of flags and liturgies, as well as rituals of religious burials for the fallen warriors.

In preparation for the battle, the generals had the duty to ensure that the proper rituals had been conducted in order for God to grant victory with minimum casualties. Taktika of Leo VI prescribes the following ritual:

4.For instance as Orthodox Christians generally deplored war and refused the sanction of killing, the Orthodox Patriarch Polyeuktos refused the petition of Byzantine 1991:1611) 5.The ritual aspect of Muslim beheadings has been recognised even by military
analysts such as Ronald $\mathrm{H}$. Jones in his report Terrorist Beheadings: Cultural and analysts such as Ronald H. Jones in his report Terrorist Beheadings: Cultural and
Strategic Implications. See the June 2005 Report cleared for public release, and published by Strategic Studies Institute, U.S. Army War College, Carlisle, PA. 
O general, before all else, we enjoin upon you that on the day of the battle your army should be free from sin. The night before, the priests are to offer fervent prayers of intercession. Everyone should be sanctified and so, by words and deeds, they should be convinced that they have the help of God (Taktika, 14.1). (Stoyanov 2014:176)

According to the same source, the flags and other military symbols needed a particular attention within ritual:

A day or two before the combat, the tourmarchs should see that the standards are blessed by the priests and then present them to the standard-bearers of the tagmata (Taktica, 13.1). (Stoyanov 2014:176)

In preparation for the battle Maurice's Strategikon prescribed:

Whether the bandon or tagma is in service with the rest of the army or is camping someplace by itself, the 'Trisagion' must be sang, and the other customary practices observed, early in the morning before any other duty and again in the evening after supper and the dismissal (Strategikon, 7.17). (Stoyanov 2014:175)

During the battle, the same source prescribed:

$[P]$ rayers should be said in camp on the actual day of battle before anyone goes out the gate. All, led by the priests, the general, and the other officers, should recite the 'Kyrie eleison' (Lord have mercy) for some time in unison. Then, in hopes of success, each meros should shout 'Nobiscum Deus' (God is with us) three times as it marches out of camp (Strategikon, 2.18). (Stoyanov 2014:175)

Leo VI also specified how those fallen in the battle should be treated:

Show particular concern for the burial of the dead .... Reverence for those who have died is always good and holy. It is especially necessary in the case of those who have fallen in battle, for it is with them that piety must manifest itself (Taktika, 16.11). (Stoyanov 2014:176)

By the 10th century, such religious rituals were part of the daily routine of the Byzantine army. As the Praecepta Militaria of Emperor Nikephoros Phokas informs, on the eve of the battle the soldiers were encouraged to ask each other for forgiveness, to fast, to confess their sins and then receive communion. Additional pre-battle rituals included the blessing of flags and weapons. After battle, proper services for the dead were observed and thanksgiving for victory was offered especially following such notable successes as the triumph of John I Tzimiskes over the Rus' in 971 (Kazhdan 1991:1373-1374).

The burial of the dead triggered the creation of ample memorial services that defined how such heroes were to be remembered by the posterity. In such a context, the violent death caused by the fury of war (or religious persecution) became associated with a particular doctrinal construal. In the name of devoutness, the real stories were skewed in ways that turned the moral qualities of a hero into archetypes of holiness. Paradoxically, the rituals constructed around such fallen heroes become epicentres for collective healing through forgiveness and reconciliation.

\section{Conclusion}

The uncontested effectiveness of ritual to create collective meaning, to concentrate political power, and to solidify the group, had been evident in the history of human civilisation. As ritual plays an ambivalent role in the encounter between religion and violence, the purpose of sacred violence is to end conflict through sacrifice and scapegoat, and to test the loyalty of the individual through initiation. Today's living religions demonstrate that sacred violence not only generates peace and war, but it also gives meaning to life. In this sense, Orthodox Christian rituals provide the believer with a set of sacred representations necessary to achieve salvation and immortality, while ensuring the damnation of those who either challenge its legitimate existence, or fail to embrace Orthodoxy. Therefore, if there is any missionary goal behind ritual, that would be the mission to make the world a safer place by fighting fire with fire or, as an Orthodox Christian paschal hymn puts it, by 'trampling down death by death'.

\section{Acknowledgements Competing interests}

The author declares that he has no financial or personal relationships which may have inappropriately influenced him in writing this article.

\section{References}

Alcorta, C.S. \& Sosis, R., 2013, 'Ritual, religion and violence: An evolutionary perspective', in M. Juergensmeyer, M. Kitts \& M. Jerryson (eds.), The Oxford handbook of religion and violence, pp. 570-577, Oxford University Press, Oxford.

Armstrong, K., 2014, Fields of blood: Religion and the history of violence, Knopf Publishers, New York.

Arocho, J., 2015, 'Coptic church recognizes Martyrdom of 21 Coptic Christians', Vatican Radio, 21 February 2015, viewed 10 February 2017, from http://www. news.va/en/news/coptic-church-recognizes-martyrdom-of-21-coptic-ch

Behr-Sigel, E. \& Ware, K., 2000, The ordination of women in the Orthodox church, WCC Publications, Geneva.

Bell, C., 1992, Ritual theory, ritual practice, Oxford University Press, Oxford.

Bilefsky, D. \& De la Baume, M., 2015, 'Terrorists Strike Charlie Hebdo Newspaper in Paris, Leaving 12 Dead', The New York Times, 7 January 2015, viewed 4 February 2017, from https://www.nytimes.com/2015/01/08/world/europe/charlie-hebdoparis-shooting.html?_r=0

Biserica Ortodoxă Română, 2000, Învățătură de credință creștină ortodoxă, tipărită cu aprobarea Sfântului Sinod al Bisericii Ortodoxe Române (București: Editura Institutului Biblic și de Misiune al Bisericii Ortodoxe Române.

Bowker, J., 1997, The Oxford dictionary of world religions, Oxford University Press, Oxford.

Braniște, E., 1978, Liturgica Teoretică: manual pentru seminariile teologice, Editura Institutului Biblic și de Misiune al bisericii Ortodoxe Române, București.

Braniște, E., 1993, Liturgica Generală cu noțiuni de artă bisericească, arhitectură și pictură crestină, ediția a II-a revizuită și completată, Editura Institutului Biblic și de Misiune al Bisericii Ortodoxe Române, București.

Carrasco, D., 2013, 'Sacrifice/human sacrifice in religious traditions', in M. Juergensmeyer, M. Kitts \& M. Jerryson (eds.), The Oxford handbook of religion and violence, pp. 209-225, Oxford University Press, Oxford.

Durkheim, E., 1969, The elementary forms of religions life, The Free Press, New York.

Eisen, R., 2011, The peace and violence of Judaism: From the Bible to Modern Zioni, Oxford University Press, Oxford.

Ferguson, J., 1978, War and peace in the world's religions, Oxford University Press, Oxford.

Frankl, V.E., 1984, Man's search for meaning, Revised and Updated, Washington Square Press, New York.

Girard, R., 1979, Violence and the sacred, transl. P. Gregory, The John Hopkins University Press, Baltimore, MD.

Gregg, H.S., 2014, The path to salvation: Religious violence from the Crusades to Jihad, Potomac Books, Lincoln, Nebraska.

Government of India, 2011, The Prevention of Insults to National Honour Act, 1971, Universal Law Publishing, Co. Pvt. Ltd., New Delhi. 
Greek Orthodox Archdiocese of America, The Service of Holy Baptism, viewed 6 February 2017, from http://www.goarch.org/chapel/liturgical_texts/baptism

Holy and Great Council of the Orthodox Church, 2016, The mission of the Orthodox church in today's world, viewed 8 February 2017, from https://www.holycouncil. org/-/mission-orthodox-church-todays-world? 101 INSTANCE VAOWE2pZ4YOI languageld=en_US

Jönsson, C. \& Hall, M., 2005, Essence of diplomacy, Palgrave MacMillan, New York.

Kazhdan, A. (ed.), 1991, The Oxford Dictionary of Byzantium, Oxford University Press, Oxford.

Kertzer, D.I., 1988, Ritual, politics, and power, Yale University Press, New Haven, CT.

Little, D., 2010, 'Response to terrorism: Statement on October 1, 2001 at Harvard University Public Meeting Concerning the Attacks of September 11', in R.L. Petersen \& M.G. Simion (eds.), Overcoming violence: Religion, conflict and peacebuilding, p. 237, Boston Theological Institute, Newton Centre, MA

MacDermot, V., 1971, The cult of the seer in the ancient Middle East. A contribution to current research on Hallucinations drawn from Coptic and other texts, University of California Press, Berkeley, CA.

McGeer, E., 1991, 'Peace and war', in A.P. Kazhdan (ed.), Oxford Dictionary of Byzantium, p. 1611, Oxford University Press, Oxford.

Mantzaridis, G.I., 2012, 'Orthodox observations on peace and war', in S. Asfaw, A. Chehadeh \& M.G. Simion (eds.), Just peace: Orthodox perspectives, pp. 117-127, WCC Publications, Geneva.

Martin, S., 2005, How to achieve total enlightenment: A practical guide to the meaning of life, Andrews McMeel Publishing LLC, Kansas City.

Nayak, A., 2000, 'Les violences dans I'hindousme', in A. Nayak (ed.), Religions et violences: Sources et interactions. Symposium, pp. 66-67, Editions Universitaires, Fribourg.

Oldenburg, H., 1988, "'Religion of the Vedas", Motilal Banarisidas, Delhi, in V. Das "Violence and Nonviolence at the Heart of Hindu Ethics"', in M. Juergensmeye $M$. Kitts \& M. Jerryson (eds.), The Oxford handbook of religion and violence, pp. 17-18, Oxford University Press, Oxford.
Pedahzur, A. \& Perliger, A., 2009, Jewish terrorism in Israel, Columbia University Press, New York.

Rakitic, D., 2014, 'Envisaging a legal framework for ensuring sustainable preservation of Holy places with regard to the Case of Kosovo and Metohia', in S. Ferrari \& A. Benzo (eds.), Between cultural diversity and common Heritage: Legal and religious perspectives on the sacred places of the Mediterranean, pp. 191-242, Ashgate perspectives on the sacred places of the
Publishing Company, Burlington, VT.

Ruthven, M. \& Nanji, A., 2004, Historical Atlas of Islam, Harvard University Press, Cambridge, MA

Scupoli, L., 1952, Unseen warfare, Faber and Faber Limited, London.

Simion, M.G., 2011, Religion and political conflict: From dialectics to cross-domain charting, Presses internationale polytechnique, Montréal.

Simion, M.G., 2012, Religion in political conflict: A constructivist theoretical model for public policy analysis, design and implementation, Doctoral Dissertation, Northeastern University, Boston, MA.

Simion, M.G., 2015, 'War and the right to life: Orthodox Christian reflections', in S. Twiss, M.G. Simion \& R.L. Petersen (eds.), Religion and public policy: Human rights, conflict, and ethics, pp. 188-206, Cambridge University Press, Cambridge, UK.

Stoyanov, Y., 2014, 'Eastern Orthodox Christianity', in G.M. Reichberg, H. Syse \& N.M. Hartwell (eds.), Religion, war and ethics: A sourcebook of textual traditions, Cambridge University Press, Cambridge.

Todoran, I. \& Zăgrean, I., 1991, Teologia Dogmatică, manual pentru seminariile teologice, Editura Institutului Biblic și de Misiune al Bisericii Ortodoxe Române, București.

Urs von Balthasar, H., 2003, Cosmic Liturgy: The universe according to Maximus the confessor, transl. B.E. Daley, S.J., Ignatius Press, San Francisco, CA.

Walasek, H., 2015, Bosnia and the destruction of cultural Heritage, Ashgate Publishing Company, Burlington, VT.

Welch, M., 2000, Flag burning: Moral panic and the criminalization of protest, De Gruyter, New York. 